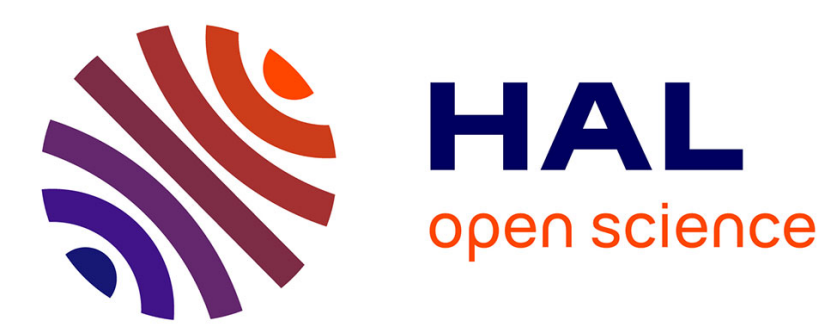

\title{
Trade creation and the status of FTAs: empirical evidence from East Asia
}

Florian Mölders, Ulrich Volz

\section{To cite this version:}

Florian Mölders, Ulrich Volz. Trade creation and the status of FTAs: empirical evidence from East Asia. Review of World Economics, 2011, 147 (3), pp.429-456. 10.1007/s10290-011-0095-9 . hal00682332

\section{HAL Id: hal-00682332 \\ https://hal.science/hal-00682332}

Submitted on 25 Mar 2012

HAL is a multi-disciplinary open access archive for the deposit and dissemination of scientific research documents, whether they are published or not. The documents may come from teaching and research institutions in France or abroad, or from public or private research centers.
L'archive ouverte pluridisciplinaire HAL, est destinée au dépôt et à la diffusion de documents scientifiques de niveau recherche, publiés ou non, émanant des établissements d'enseignement et de recherche français ou étrangers, des laboratoires publics ou privés. 


\title{
Trade Creation and the Status of FTAs - \\ Empirical Evidence from East Asia ${ }^{1}$
}

\author{
Florian Mölders, DIW Berlin ${ }^{2}$ \\ Ulrich Volz, German Development Institute ${ }^{3}$
}

\begin{abstract}
East Asia has been considered a latecomer with respect to Free Trade Agreements (FTAs). Since the turn of the last century, however, FTAs with East Asian participation have seen an intra-and extra-regional expansion. Many trade initiatives have been proposed, negotiated or even implemented. This introduces interesting perspectives for the analysis of trade agreements regarding their anticipatory trade effects. This paper focuses on the trade impact of FTAs at different stages that East Asian economies participate in. The central part of this study is an econometric analysis that applies panel data to the gravity model of international trade flows. We augment the traditional model with variables to estimate trade effects of bilateral and multilateral agreements and year-to-year changes in the stages of their implementation. Our results reveal that there exist anticipatory effects preceding the actual implementation of bilateral FTAs with East Asian participation. Further, anticipation effects are larger for bilateral than for multilateral agreements, possibly because the realisation of bilateral agreements is considered more realistic.
\end{abstract}

JEL Classification: F13

Keywords: Free trade agreements; trade; East Asia; gravity model; panel data.

\footnotetext{
${ }^{1}$ The authors would like to thank Birgit Schmitz, Jürgen von Hagen, Ansgar Belke, Jörg Breitung, James Reade and an anonymous referee for helpful comments. The usual disclaimer applies.

${ }^{2}$ Address: DIW Berlin, Mohrenstraße 58, 10117 Berlin, Germany. E-mail: fmoelders@ diw.de.

${ }^{3}$ Address: German Development Institute, Tulpenfeld 6, 53113 Bonn, Germany. E-mail: ulrich.volz@die-gdi.de.
} 


\section{Introduction}

East Asia is considered to be a latecomer to Free Trade Agreements (FTAs). By the mid1990s the region had significantly fewer trade agreement initiatives than Europe or the Americas. Nevertheless, since 2000, many initiatives were proposed, negotiated, and even implemented. ${ }^{4}$ FTAs with East Asian participation are concentrated within the region but have also seen extensions to extra-regional trading partners throughout the world. This introduces interesting perspectives for the analysis of trade agreements. Using trade data for 14 East Asian countries, ${ }^{5}$ this paper focuses on the impact that FTAs have on trade at the different stages that East Asian economies participate in. ${ }^{6}$ The central part of this study is an econometric analysis using panel data with the gravity model of international trade flows. To complement the discussion about anticipatory trade effects in the dimension of preimplementation status, we control for year-to-year changes in the stages of the respective FTAs.

We use suitable econometric methods to account for the potential endogeneity problem, which occurs due to the inclusion of the FTA variable and the dubious causal relationship with the volume of trade. Additionally, we distinguish between bilateral and multilateral FTAs as these forms of trade agreements may have different trade effects, due to the expectation that either bilateral or multilateral FTAs are more likely to trigger increasing bilateral trade. If this is the case, our variables in the econometric specification will reflect this difference. As we are particularly interested in the anticipatory effects of the agreements, the included variables distinguish between all (pre-) implementation stages of bilateral and multilateral FTAs.

Our results reveal at least three interesting findings: first, there are anticipatory effects preceding the actual implementation of bilateral FTAs with East Asian participation. In particular, the stage during which bilateral agreements are (close to) being negotiated exposes significant positive trade effects. Secondly, we found no significant anticipatory trade impact for multilateral trade agreements. Thirdly, the fact that we obtain somewhat contradictory results using different regression techniques - including pooled ordinary least squares, generalised least squares (GLS) with random effects, Tobit regression with random effects as

\footnotetext{
4 Throughout this paper, we will use the terms implemented (under implementation) and in effect interchangeably.

5 These are: Brunei Darussalam (hereafter Brunei), Cambodia, People's Republic of China (hereafter China), Hong Kong SAR (hereafter Hong Kong), Indonesia, Japan, Republic of Korea (hereafter Korea), Lao People's Democratic Republic (hereafter Laos), Malaysia, Myanmar, Philippines, Singapore, Thailand and Vietnam.

${ }^{6}$ In the subsequent analysis, we use the term FTA to describe various forms of trade enhancing initiatives such as preferential trade agreements, customs unions and of course FTAs. According to Vicard (2009), the trade creation effect of different categories of trade agreements does not vary significantly.
} 
well as the fixed effects estimations of GLS, Poisson and negative-binomial - using identical data, highlights the need for a careful selection of the most appropriate econometric methodology.

The remainder of the paper is structured as follows: Section 2 provides an overview of trade integration and trade agreements in East Asia. Section 3 then reviews the empirical literature on trade-creating effects of FTAs, with a focus on previous studies that examine anticipatory effects. In Section 4 we introduce our econometric methodology and our data, which is followed by a presentation of our results in Section 5 and conclusions in Section 6.

\title{
2. Background: trade integration and trade agreements in East Asia
}

\author{
"When it comes to East Asian regionalism, the state of play is easily \\ summarised - it is a mess." \\ (Baldwin 2006: 5)
}

Since 2000, an unprecedented surge in the development of trade agreement initiatives has occurred. Together with other Asian Pacific states, East Asia recorded the fastest growing concentration in FTAs. Kawai (2007) and others hold multiple events responsible for the increasing number of East Asian FTAs. The main thrust behind institutionalised regional economic integration in East Asia is the ever-growing economic interdependence of the countries. It is the market-driven regionalisation (Langhammer 2007) that took off in the 1980s that was responsible for the growing interdependence in East Asia, leading to factory Asia as labelled by Baldwin (2006). Baldwin argues that East Asian regionalism can be classified into stages. The first, closely linked to the phenomenon of factory Asia, took off when Japan was in need of low-skilled labour due to an extraordinary increase in domestic incomes and the subsequent loss of comparative advantage in the production of labourintensive goods. This resulted in outsourcing and induced a build-up of vertical production networks throughout East Asia, accompanied by the hollowing-out of the Japanese economy. Throughout the outsourcing period, from the mid-1980s and during the 1990s, developing East Asia $^{7}$ experienced a remarkable surge in FDI inflows that considerably shaped the regional economic architecture (ADB 2006). The rising FDI inflows contributed to an increase in intra-industry and intra-regional trade, resulting from labour-seeking and

\footnotetext{
${ }^{7}$ Developing East Asia refers to the ten ASEAN members and the NIE (Newly Industrialised Economies), namely Hong Kong, Korea and Taiwan.
} 
component-outsourcing FDI (Kawai 2004). ${ }^{8}$ Both forms of FDI are aimed at making use of comparative advantages and responsible for successfully networking the region. The increasing FDI inflows in East Asia "recycled" comparative advantages by upgrading the leading economies' production and allowing less developed economies to replace labourintensive industries previously dominated by the more developed countries.

Economic integration demanded further steps towards institutionalisation as weaknesses in economic cooperation became apparent during the Asian crisis. This marked a turning point as the economic interdependence became obvious in its most negative form. The lack of cooperative mechanisms that might have avoided the contagious spread of the crisis across the region became apparent. The incapability of existing trade cooperation initiatives like the ASEAN Free Trade Area (AFTA) to cushion the crisis' effects enforced the political will in the East Asian economies for further financial and trade integration and signalled that de facto economic integration would demand de jure initiatives, thereby forming a common sense of solidarity (Kawai 2007). ${ }^{9}$

Furthermore, the increasing regionalisation in Europe (EU) and the Americas (NAFTA, MERCOSUR) left Asian countries out of the FTA game, resulting in a fear that East Asian goods would be discriminated against in the respective regional groupings (Kawai 2007). ${ }^{10}$ This is consistent with the "isolation avoidance" motive where East Asian economies recognised the advantages of being institutionally connected to its trading partners (Dent 2006). In contrast to the trade-production motives that led to the increased regionalism in East Asia, FTAs with countries outside of the region are mostly export motivated and aimed at gaining access to extra-regional markets. Accordingly, the importance of export-led growth in East Asia is stressed by Dobson (2001), who claims that the stagnation of multilateral trade liberalisation in the 1999 Seattle WTO talks caused East Asia to pursue its own intra- and extra-regional FTAs. ${ }^{11}$

East Asian countries' trade linkages provide a heterogeneous picture of East Asia's direction of trade and its FTA policies. As Baldwin (2006) points out, trade integration in East Asia is characterised by overlapping trade agreements via bilateral and multilateral FTAs

\footnotetext{
${ }^{8}$ For a comprehensive overview on the effects of regional integration agreements on FDI see Blomström and Kokko (1997).

${ }^{9}$ Regional initiatives have been initiated that are supposed to cushion negative shocks that could result in overlapping effects for the region. The Chiang Mai Initiative (launched in 2000) and Asian Bond Market Initiative (launched in 2003) are the most prominent ones.

${ }^{10}$ Baldwin's (1993) domino theory helps to comprehend East Asia's fear of discrimination: the costs of nonmembership increase when trading partners (e.g. USA, Europe) enter existing trade agreements as members' trade within an agreement is treated preferentially. For reference on this issue in the context of East Asia, see Dent (2006).

11 Medvedev (2010) shows that between 2000 and 2002, only 12\% of total trade in East Asia was conducted under preferential trade agreements.
} 
leading to the "Noodle Bowl" syndrome. This obscure status quo displays similarities to Bhagwati's (1995) "Spaghetti Bowl” that describes overlapping regulations and different rules of origin. The danger herein is that the intended trade facilitation of FTAs backfires due to multiple trade and tariff regulations that are unclear. In the case of East Asia, there are several examples of overlapping FTAs at the bilateral and multilateral level. The Sino-Thai trade relations provide a good example: China is linked with Thailand via two implemented FTAs: the bilateral People's Republic of China-Thailand Free Trade Agreement and the multilateral ASEAN-China Comprehensive Economic Cooperation Agreement. Additionally, the proposed East Asian Free Trade Area between the ASEAN+3 countries would add a third FTA between China and Thailand.

As of September 2008, there were 110 FTAs, bilateral and multilateral, connecting East Asian economies both within and outside the region (see Table 3 in the Appendix and Figure 1). Most of these agreements were at pre-implementation stage. Five (pre-) implementation stages are distinguished: proposed, framework agreement signed, under negotiation, concluded and in effect. ${ }^{12}$ Singapore, Thailand, China and Korea stand out with the most initiatives and in that the majority of the agreements are with partners from outside the region. The other East Asian countries stand in contrast: significantly fewer FTAs that are mostly with partners from within the region. When it comes to trade agreements in the final stage (in effect), the dominance of extra-regional FTAs of the four frontrunners is weakened. Of the in effect FTAs for China, a slight majority were extra-regional. For Thailand it is reversed: a majority are intra-regional, as the only concluded agreements outside East Asia are with Australia and New Zealand. Singapore had, as of 2008, implemented almost half of its initiatives and Korea less than a quarter.

In order to evaluate the pace of negotiations of bilateral and multilateral agreements, we have calculated the average time period (in years) that it takes for an initiative to switch from one stage to the next: bilateral agreements take about two and a half years to reach a higher stage of implementation, whereas the multilateral ones need almost three years. ${ }^{13}$ This gives rise to the impression that bilateral FTAs are easier to negotiate and guarantee a faster implementation.

[Figure 1 and Table 1 about here.]

\footnotetext{
${ }^{12}$ See Table 1 for the definitions of the respective stages.

${ }^{13}$ It is worth mentioning that there are outliers in the data on bilateral FTAs. Agreements with the United States e.g. tend to be stuck in one stage for a considerable amount of time which distorts the average number of years upwards. The United States - Indonesia FTA, which stands at the proposed stage since 1997, is an example.
} 
As of 2008, the strengthening of intra-regional trade relations in East Asia resulted in 22 intra-regional FTAs from the proposed through implemented stages. Out of these intraregional agreements, almost two-thirds were either signed or are in effect. Extra-regional FTAs reflect an inverted picture, consisting of a mere $26 \%$ of implemented and concluded FTAs. The comparison in the numbers between intra- and extra-regional implemented FTAs is mirrored by the trade orientation of East Asia which is characterised by high intra-regional trade.

Figure 1, which depicts the evolution of FTAs with East Asian participation, visualises the remarkable increase at the turn of the millennium. After the Asian crisis, the 1999 breakdown of WTO trade negotiations in Seattle, and China's accession to the WTO in 2001, FTA initiatives surged and a few East Asian countries set the tone. Those disappointed by the slow pace of the liberalisation process with its main trading partners through WTO negotiations in 1999 and 2003 found an alternative: establishing bilateral FTAs.

\section{Literature review: anticipatory trade-creating effects of FTAs}

Several studies look into the possible anticipatory effects, which would alter the bilateral trade volume, of trade agreements at pre-implementation stage. Freund and McLaren (1999) find evidence of anticipatory investments before trade agreements become effective. They attribute their findings to adjustment effects in the business environment that are needed in advance to be prepared for the period in which the FTA is implemented. On the issue of trade related anticipation, Eichengreen and Irwin (1996) argue that FTAs are often preceded by less official agreements that lead to an orientation towards an expected formal FTA. This reorientation may also be based on the adjustment of suppliers who redirect exports in anticipation of the future agreement. In the case of the North American Free Trade Agreement (NAFTA), Kose et al. (2004) show that there was an anticipation effect before NAFTA became effective that triggered dynamic trade and financial flow effects. ${ }^{14}$ Croce et al. (2004) argue that anticipation depends strongly on the belief that the agreement will be implemented. Hence, smooth negotiations might increase the probability of an FTA being concluded. This would suggest that an initial anticipation effect should be visible while the FTA is in the negotiation stage.

\footnotetext{
${ }^{14}$ In another empirical analysis on NAFTA, Krueger (1999) finds that trade relations between Canada, the United States and Mexico were affected even before the FTA became effective. According to Krueger, this was not entirely attributable to the anticipation of NAFTA but also to the liberalisation process prior to 1994 (when NAFTA was implemented) that took place in Mexico.
} 
As the duration of trade negotiations varies widely, ${ }^{15}$ depending on what trade issues are being discussed (agriculture, industry, services), a mere look at the foregoing periods does not give satisfactory insight into how the status of FTAs actually influenced bilateral trade flows.

Magee (2008) investigates anticipation and lagged effects of FTAs in a panel data analysis of 133 countries between 1980 and 1998. His conclusions strongly suggest the existence of anticipatory trade effects. More precisely, trade increases, on average, by $26 \%$ in the four years prior to trade agreement implementation.

With respect to East Asia, Elliott and Ikemoto (2004) analyse the trade creating effects of the ASEAN FTA (AFTA) before and after its implementation with a special focus on possible anticipatory trade effects. Their results indicate that no significant trade creating effects were observed in the periods following its implementation in 1992. In contrast, trade effects appeared in the period leading to the singing of AFTA. Their estimates are based on pooled data from several time periods instead of making use of panel data and its adjunct econometric features like fixed effects estimation and the possible removal of time invariant unobservable effects. Elliott and Ikemoto though employ a variable that controls for the complementarities of the respective country pair's in their factor endowments and furthermore include variables that incorporate trade-creation and -diversion effects. We omit such variables from our analysis as our focus is strictly on the anticipatory effects of trade agreements.

In accordance with these results, Coulibaly (2006) estimates the anticipation effects of AFTA to be positive by pointing at increasing exports and imports five years before the agreement became effective. The author not only focuses on AFTA but also refers to other RTAs and their respective anticipatory effects. Regional groupings such as the Southern African Development Community (SADC) and the Economic Community of West African States (ECOWAS) saw member trade flows increasing in the years preceding the actual implementation. Coulibaly incorporates the anticipation of trade agreements via the inclusion of a fixed lead variable meant to represent the negotiation of an agreement.

None of the aforementioned studies on anticipatory effects distinguish directly between the different stages of implementation of the respective agreements but rather focus on foregoing time periods that are not necessarily linked to any particular (pre-) implementation stage. Our study complements previous research by taking into account the degree of implementation for the respective agreements. Our goal is to contribute to the

15 Dent (2006: 18) provides the example of the Japan-Mexico Economic Partnership Agreement whose negotiations took 14 rounds. 
discussion on anticipatory trade effects by including a higher level of sensitivity and going beyond a mere look at preceding time periods.

\section{Methodology and data}

The gravity model is the workhorse for the analysis of international trade relations and especially the analysis of bilateral trade flows. It is based on Newton's observation that the gravity among two objects is positively proportional to their masses and adversely to the distance between them. It was introduced to economics by Tinbergen's "Analysis of World Trade Flows" (Tinbergen 1962: 262 ff.). Further empirical work was conducted by Linnemann (1966) but theoretical justification still lagged. Anderson (1979) and Bergstrand (1985), among others, introduced the needed theoretical background. ${ }^{16}$

\subsection{The baseline model}

The basic gravity equation states that the trade between two countries is positively related to economic masses, as reflected by the countries' GDPs, and negatively by the distance between them. Economically, this means on the one hand that the more a country pair produces (the higher the product of the two GDPs), the greater the trade between the two. On the other hand, transportation costs (which increase the price that the consumer will have to pay in the importing country) will rise with increasing distance, and hence reduce bilateral trade.

In its most reduced form the gravity model includes only the respective GDPs and distance as explanatory variables for bilateral trade flows. For our model specification, we include several other variables to the basic gravity equation, so that it takes the following form:

\footnotetext{
${ }^{16}$ A considerable number of authors contributed to the further development and justification of the gravity model. Further inputs include Pöyhönen (1963) and Helpman (1987). For a comprehensive summary on the theory of the gravity model, see Deardorff (1995) or Feenstra (2004) who review the relevant contributions in this field. Anderson and van Wincoop (2003) criticise the existing setup of the gravity equation on the grounds of missing multilateral resistance terms which shall reflect a country pairs' relative position to the rest of the world economy in addition to the bilateral resistances, such as the distance between its trading partners.
} 


$$
\begin{aligned}
& \ln \left(T_{i j t}\right)=\beta_{0}+\beta_{1} \ln \left(D_{i j}\right)+\beta_{2} \text { Border }_{i j}+\beta_{3} \text { Language }_{i j}+\beta_{4} \ln \left(G D P_{i t} G D P_{j t}\right) \\
& +\beta_{5} \ln \left(\text { Pop }_{i t} \text { Pop }_{j t}\right)+\beta_{6} W_{i j t}+\beta_{7} I_{i j t}+\varepsilon_{i j t} .
\end{aligned}
$$

For interpretative reasons, the variables are log transformed in order to mirror the percentage increase/decrease in the dependent variable due to a change in the explanatory variables. The dependent variable $T_{i j t}$ reflects the total bilateral trade volume in nominal USD between countries $i$ and $j$ (exports plus imports) in period $t .^{17}$ The explanatory variables in

\begin{tabular}{|c|c|}
\hline$D_{i j}$ & Distance between country $i$ and $j^{18}(-)$ \\
\hline$G D P_{i t} G D P_{j t}$ & Product of the countries' GDPs $(+)$ \\
\hline Language $i j$ & Common official language $(+)$ \\
\hline Borderij & Common border $(+)$ \\
\hline PopitPopjt & Product of the countries' populations (-) \\
\hline$W T O_{i j}$ & Both trading partners are members of the WTO $(+)$ \\
\hline$I_{i j t}$ & Variable describing FTAs between $i$ and $j$ in its various stages (?) \\
\hline
\end{tabular}
Equation (1) are denoted as follows (with expected signs in parentheses):

$G D P_{i t} G D P_{j t}$ denounces the product of the GDPs of countries $i$ and $j$. The distance between $i$ and $j$ is labelled as $D_{i j}$. In order to properly uncover the determinants of bilateral trade flows, we include several additional explanatory variables on the ground of empirical justification in the literature. ${ }^{19}$ Sharing the same official language as well as having a common border is expected to increase bilateral trade flows. The former via trade facilitation ${ }^{20}$ and the latter through lower transportation costs, since a common border allows goods to be traded without using a transit country through which the goods must be transferred. A factor that reflects the self-sufficiency of the respective country pairs is added with the introduction of the population variable (see Frankel 1997). Countries with a higher population are expected to

\footnotetext{
${ }^{17}$ We concentrate on nominal trade flows instead of real flows due to data availability. There are no export or import deflators on hand for the respective countries. Only a few authors record whether they use real or nominal data. Among those who do, some follow Rose (2004) and obtain real values by deflating the nominal trade flows by the US CPI. This is criticised by Baldwin and Taglioni (2006), who state that this method is biased, as export/import deflators are needed. Following Frankel (1997), we include time dummies in each regression to account for effects of global inflation and growth that are common to all country pairs in any year.

${ }^{18}$ We use distance according to the great distance formula which makes use of the countries' most populous agglomerations.

${ }^{19}$ For a comprehensive overview on possible variables in the gravity model and further references see Ghosh and Yamarik (2004).

${ }^{20}$ Melitz (2008) recently emphasised the positive influence of a common language on the volume of bilateral trade.
} 
be less dependent on international trade as the available natural resources (land size is approximated by the product of the countries' populations) as well as the domestic market should be positively correlated with population size. The anticipated sign of this variable thus is negative.

We also include a dummy variable indicating whether both countries are members of the World Trade Organisation (WTO). Previous research suggests that joint WTO membership should increase a country pair's trade (Rose 2004; Subramanian and Wei 2007; Helpman et al. 2008; Balding 2010). WTO membership can be interpreted as a proxy for the countries' willingness to further integrate into the world economy. ${ }^{21}$ Empirical findings on the positive trade effects of WTO membership is relatively consistent even though there are differences in the magnitude of the effect if one compares industrialised and developing countries (Subramanian and Wei 2007). It remains without question that, for a proper empirical analysis of trade effects, the time varying variable incorporating WTO membership ought to be included whenever a panel data set is used. Our variable is a dummy that signals whether both countries are WTO members.

The term $I_{i j t}$ in equation (1) refers to the variables describing the FTAs in its various stages and will be discussed in the following section. The cornerstone of our analysis is the analysis of trade effects during the different stages of implementation for the various trade agreements involving East Asia. The econometric specification, as well as other variables included in the regressions, plays an important role when it comes to the validity and significance of the results.

Finally, $\varepsilon_{i j t}$ is the error term that includes both the idiosyncratic error $u_{i j t}$ as well as the (unobserved) country pair-specific term $a_{i j}$, being constant over time. The latter error plays a key role in the fixed effects specification discussed in section 4.3, as unobserved heterogeneity in the country pairs may be cancelled out, which reduces the endogeneity problem.

Trade data for the period 1995-2007 are drawn from the IMF's Direction of Trade Statistics (2008). GDP and population data are from IMF's World Economic Outlook (2009) database. The distance, border, and language data are from CEPII (2009). For the WTO dummy, we used the information given on the homepage of the WTO. ${ }^{22}$ We constructed a comprehensive data set covering total trade between all East Asian countries as well as trade with 78 countries outside of the region (see table 4 in the Appendix). Regarding the extra-

\footnotetext{
${ }^{21}$ Consider the examples of China and Vietnam. Vietnam's accession to the WTO in the beginning of 2007 was expected to boost FDI (Hau and Dickie 2006) similar to the boost that occurred with China's 2001 accession.

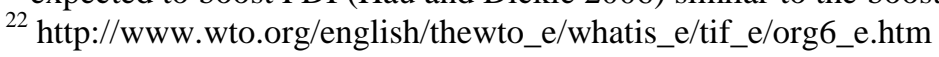


regional partners, we included every country with at least one connection to an East Asian country via an FTA (irrespective of the status this FTA is in at period $t$ ). ${ }^{23}$ This gives a total of 15,379 observations, ${ }^{24}$ of which 15,017 are used for the estimation. The remaining trade values are missing from the data set. Out of the available observations, $13.49 \%$ are zero observations. This is of particular importance when it comes to the Poisson and Tobit regressions as these specifications allow us to include zero observations in the analysis.

\subsection{Differentiating for FTAs at different stages}

Most of the empirical literature on FTAs focuses on an intuitive but superficial method to include the effects of trade agreements into the regression analysis: to include a dummy variable which takes the value 1 if an agreement is implemented to capture its trade effects from the implementation period $t$ on, and 0 otherwise. This approach has several weaknesses, one of which we try to deal with in this study: the anticipation of agreements well in advance of the actual implementation. ${ }^{25}$

In our study, we differentiate between five stages of a trade agreement: (1) proposed, (2) framework agreement signed, (3) under negotiation, (4) signed and (5) in effect. The respective definitions follow our data for the respective FTAs with East Asian participation, the ADB Regional Integration Center (2009). This database contains all the relevant information for any trade agreement that any East Asian economy participates in. The data covers from 1995 through the end of 2007. Therefore, we are able to source information for the regressions not only from cross-sectional but also from time variant data.

We incorporate the status variables in the regression by using a very simple but effective method: whenever an FTA initiative is proposed, negotiated or concluded in period $t$, a respective dummy variable reflects this status. We bring in dummies for bilateral as well

\footnotetext{
${ }^{23}$ In order to address the concerns raised by Haveman and Hummels (1998), who argue that gravity model estimates are sensitive to the sample of countries included, we have run robustness checks with different sample selections, such as adding more countries according to the total average trade volume with East Asia or by GDP, without significantly altering our results.

${ }^{24}$ This number has been calculated as follows: For each of the 14 East Asian countries, we include 78 extraregional trading partners over the period of 13 years $(78 \times 13 \times 14=14,196$ observations). There are 13 intraregional trading partners for the first East Asian economy, 12 for the second, etc., resulting in 1,183 observations $((13+12+11+10+9+8+7+6+5+4+3+2+1) \times 13)$. This adds up to 15,379 observations for East Asia's intra- and extra-regional trade relations.

${ }^{25}$ A single dummy variable prevents the differentiation between the different types of FTAs. Trade agreements may include different kinds of trade facilitation measures, or even promote FDI or monetary cooperation among the signatories. A more sophisticated analysis should incorporate and reflect trade effects coming from different types of trade agreements in order to assign the effects to certain measures. Magee (2008), for example, distinguishes between FTAs, customs unions, and preferential trade agreements.
} 
as multilateral trade agreements resulting in ten dummy variables for the regression analysis. The resulting signs and significance levels of the variables will show us which stage of the implementation process had what effect on the bilateral trade volume.

Concerning the stages of multilateral FTAs, it may occur that a country pair has overlapping FTA initiatives at various levels such as a proposed agreement as well as one that is near completion. Korea, for example, has the proposed ASEAN+3 framework and the ASEAN-Korea Comprehensive Economic Cooperation Agreement completed in 2007. In such a case, the agreement at the latest stage enters the regression analysis. Therefore, ASEAN+3 is omitted in favour of the second, "higher ranked" FTA. Since this leaves out the possibility of observing additional effects coming from the preliminary ASEAN+3 agreement, we also compute another specification that includes possible scale effects of multiple, overlapping trade agreements. These results are not reported here since the significance as well as the contribution to the discussion on anticipatory trade effects was negligible. ${ }^{26}$

\subsection{Addressing the possible endogeneity of the FTA variable and other complications}

When the effects of FTAs on trade flows are analysed, cautious treatment of the FTA variable is a technical imperative. The problem arises through the nature of FTAs whose establishment is based on a variety of factors, political and economic. Not only do FTAs affect bilateral trade flows, but already intense trade relations may lead to its institutionalisation, indicating that market-driven integration is followed by institutions aimed at facilitating trade flows through the removal of trade barriers. Econometrically this is problematic, as the explanatory variable must be considered endogenous as it is correlated with the error term. If an explanatory variable is correlated with the error term and unobserved effects incorporated in the error term simultaneously influence the independent and dependent variables, ordinary least squares estimates are biased. In our case, it remains unclear whether trade increases through the establishment of FTAs or vice versa. Strong trade relations could well trigger an institutionalisation of economic relations; that is, market-driven precedes institutionalised trade integration. The possibility of biased estimates (without proper adjustment of the gravity model) may be expected in the case of intra-East Asian trade where FTAs have long been neglected and market driven integration preceded institutionalisation.

\footnotetext{
${ }^{26}$ This method directly reflected the natural ordering of the degrees of implementation; from the proposed until the concluded stage. The five stages have been ordered in an ascending manner from 1 (proposed) to 5 (in effect). For overlapping, multilateral FTAs, we summed the numbers to incorporate scale effects coming through multiple trade agreements. The results are available from the authors upon request.
} 
The literature began to pay attention to this issue starting with Baier and Bergstrand (2002), who analyse the factors influencing the establishment of FTAs. In a subsequent study, Magee (2003) shows that higher trade flows increase the probability of country pairs to establishing an FTA. Even though there is a discussion about the "natural trading partners" hypothesis (Wonnacott and Lutz 1989), the technical perspective of estimating FTA effects using the gravity model with endogeneity controlled specifications has long been neglected.

In general, there are two ways that the endogenous variables can be accounted for: instrumental variables (IV) estimation and the application of fixed effects. With respect to IV estimation, Baier and Bergstrand (2004) investigate the determinants of FTAs adding the differences in capital/labour ratios and per capita GDPs and political variables as instruments. $^{27}$ The method of eliminating the endogeneity through IV is intuitive but in practice, this is diluted due to weak instruments and the resulting biased results (see Baier and Bergstrand, 2007). We tried specifying the model according to IV with the inclusion of the World Bank Governance Indicators (see Kaufmann et al. 2008), using the indicators of voice and accountability, political stability, government effectiveness, regulatory quality, rule of law, and control of corruption. ${ }^{28}$ However, these instruments were weak, as identified by an overidentification test. $^{29}$

Baier and Bergstrand (2007) employ another method that does not need additional explanatory variables or instruments, but rather relies on eliminating unobserved effects, such as existing intense trade relations. Fixed effects incorporate any unobserved, time invariant influences and clear out possible correlations between the regressors and the error term. If a country pair has traded intensively in the past and this remains unexplained by the standard gravity variables, then this might point towards unobserved heterogeneity, which is controlled for by using fixed effects. Colonial ties that increase the probability of an FTA between a country pair are an example of unobserved heterogeneous fixed effects that we leave of out of our econometric analysis as we focus on the fixed effects results that would remove the respective coefficient of the colonial ties variable anyway. Baier and Bergstrand (2007) as well as Magee (2008) use fixed effects and stress their appropriateness for handling the endogeneity bias. $^{30}$

\footnotetext{
${ }^{27}$ Their results show that differences in capital/labour ratios (making use of comparative advantages), proximity of the respective trading partners and similarity of the countries' GDP (exploiting economies of scale) among others are significant determinants of FTAs. The authors correctly predicted $97.29 \%$ of trade agreements.

${ }^{28}$ Political factors as a driving force for FTAs has been examined by Mansfield et al. (2002) and Rosendorff (2005) and their findings suggest that democratic country pairs favour bilateral trade liberalisation, as do dyads of autocracies.

${ }^{29}$ The results are not reported here but are available from the authors upon request.

${ }^{30}$ Caporale et al. (2009) refer to the fixed effect vector decomposition method if estimation is based on a small sample.
} 
Other issues regarding the endogeneity bias may result from the GDP variables that are only sporadically discussed in the literature. Trade enters the GDP in the national accounts but as the gravity equation only considers bilateral trade flows, these are not expected to have a large impact on a country's GDP. Therefore, we refrain from specially treating the GDP variable in our analysis.

Besides the treatment of endogeneity for the FTA variables, a number of other issues need to be taken into consideration in order to properly estimate the model and to come up with an econometric specification accommodating the characteristics of panel data. One important problem arises from the existence of zero trade flows in the gravity equation since the gravity equation uses log-transformations. As no logarithm of zero exists, Frankel (1997) describes three approaches that are widely applied: the researcher can omit the zero entries and estimate the equation without those observations; but these nevertheless carry important information as the explanatory variables describe non-existing trade. This leads to a sample selection bias that can be corrected for by implementing a two-step method that first estimates the probability for two countries having zero trade and then uses these predicted values for the gravity estimates (see Helpman et al. 2008). Second, zero trade flows can be replaced with arbitrary small numbers to prevent sample selection. The obvious disadvantage is the modification of the data set. As a third approach, we can add 1 to the trade volume and then transform it into $\log$ s that then lead to zero values (in $\operatorname{logs}$ ). Again, the drawback is the arbitrary nature of this transformation. The advantage though is that the Tobit model includes all possible observations and takes the censored nature of the data (bounded from below by zero) into account.

Santos Silva and Tenreyro (2006) propose using a Poisson pseudo maximum likelihood estimator that allows for zero entries in the data for the dependent variable. ${ }^{31} \mathrm{By}$ means of this model, the dependent variable is not transformed into logarithms and the estimated equation changes into:

$$
\begin{aligned}
& T_{i j t}=\beta_{0}+\beta_{1} \ln \left(D_{i j}\right)+\beta_{2} \text { Border }_{i j}+\beta_{3} \text { Language }_{i j}+\beta_{4} \ln \left(G D P_{i t} G D P_{j t}\right) \\
& +\beta_{5} \ln \left(\text { Pop }_{i t} \text { Pop }_{j t}\right)+\beta_{6} W T O_{i j t}+\beta_{7} I_{i j t}+\varepsilon_{i j t} .
\end{aligned}
$$

The use of the Poisson model leads over to the treatment of heteroskedastic error terms. The estimator in the standard gravity model (even controlling for fixed effects) may be biased due to measurement errors and heteroskedastic error terms. According to Santos Silva

\footnotetext{
${ }^{31}$ For further justification of the Poisson model in non-count models, see Winkelmann (2008) and Wooldridge (2002) who recommend Poisson due to its properties under the existence of heteroskedasticity.
} 
and Tenreyro (2006), the standard gravity model is misspecified. They favour the use of the Poisson estimation that is robust in the case of heteroskedastic error terms and measurement errors in the log-transformed variables. ${ }^{32}$ Santos Silva and Tenreyro (2006) note that even if the proportionality condition $E(Y \mid X) \propto \operatorname{Var}(Y \mid X)^{33}$ does not hold strictly, ${ }^{34}$ Poisson is more adequate than models that rely on the homoskedasticity assumption. In our case, we estimate the Poisson model but our data reflects overdispersion ${ }^{35}$, which demands a negativebinominal distribution in order to estimate the coefficients properly (see e.g. Allison and Waterman 2002; Soloaga et al. 2006). This method basically refers to a Poisson model that accounts for overdispersion ${ }^{36}$ while still allowing for the inclusion of zero-trade flows. ${ }^{37}$

\section{Empirical results}

To ensure an appropriate interpretation of the various variables and highlight the partly inconsistent results of the different approaches, we present the estimates of six different specifications: pooled ordinary least squares (POLS), generalised least squares with random effects (GLS RE), Tobit regression with random effects (Tobit RE) as well as the fixed effects estimations of GLS (GLS FE), Poisson (Poisson FE) and negative-binomial (NB FE). Bilateral as well as multilateral FTA stages are included, which yields ten dummy variables. Overlapping multilateral agreements are treated as described above, using the highest multilateral FTA status between two countries.

Table 2 presents the respective regression results, including the results of the POLS regression, which ignores the panel characteristics of the data, to illustrate the differences between the specifications. Even though there are differences in the magnitude of the respective effects, which are mainly attributable to the respective econometric specification, the major features of the standard gravity model are confirmed throughout our analysis. The coefficients of the standard variables (distance, GDP, population, common border and common language) are largely consistent with our expectations. The distance variable which

\footnotetext{
${ }^{32}$ An empirical application of the Poisson method for gravity models can be found in Magee (2008).

${ }^{33} Y$ denotes the dependent variable (in our case, trade flows between $i$ and $j$ ). $X$ refers to the explanatory variables.

${ }^{34}$ This would violate the equidispersion condition in the Poisson model.

${ }^{35}$ In our case, a likelihood-ratio test rejects the hypothesis that the Poisson and negative-binomial distributions are equivalent, pointing towards overdispersion.

${ }^{36}$ Overdisperion is characterised by an increasing ratio of the variance to the conditional mean (Wooldridge 2002).

${ }^{37}$ For empirical analyses employing a negative-binomial distribution, we refer to Soloaga et al. (2006) and Fratianni and Marchionne (2009).
} 
measures the great circle distance between the two nations' most important agglomerations is significantly negative for all specifications, with estimates for a trade-decreasing effect for a doubling in the distance ranging from $112 \%$ (GLS RE) and $98 \%$ (POLS) to $51 \%$ for the negative-binomial fixed effects approach. Similar results are obtained for the variables indicating a common language or the product of the respective countries' GDPs. Both coefficients are significantly positive but reflect decreasing magnitude when controlling for overdispersion and inclusion of zero-trade observations. An increase of the product of the output of the country pairs by $100 \%$ increases bilateral trade by $47 \%$, up to $122 \%$ depending on the applied method. The coefficient estimates of the population variable are largely in line with our expectations.

[Table 2 about here.]

Turning to the effect of trade agreements, throughout the various specifications, the WTO dummy is significant at the $1 \%$ level and reveals a positive trade effect of $33.64 \%^{38}$ without controlling for the panel structure and any peculiarities in the POLS specification up to $63.23 \%$ in the negative-binomial regression. This suggests a strong and highly robust effect of WTO membership in the case of bilateral trade relations with East Asia.

The FTA status dummies are of special interest as these indicate the effect on bilateral trade at the individual stage compared to a situation in which two countries do not share any common FTA status. Considering bilateral FTAs, the coefficient estimates for the proposed agreement variable are positive for all the regression methods applied. Importantly, the estimate we get with negative-binomial is not only positive but also significant, indicating the existence of an anticipatory effect. As previously noted, we consider the negative-binomial approach the most appropriate due to overdispersion in the data. We also obtain robust results for the signed framework agreement variable, which is significantly positive for all regressions except Poisson. The coefficient of the negative-binomial signals an increase in the bilateral trade volume of $39.10 \%$. In comparison, the fixed effect equivalent of the GLS method estimates an increase of $20.92 \%$, which is also significant. Except for the POLS regression, the results for the under negotiation stage are insignificant, which suggests that the anticipatory effects come into play during an earlier stage. We obtain mixed results for the stages of completion variables, namely the signed and in effect variables. Regarding the former, we find a weakly significant but negative sign in the negative-binomial and a

\footnotetext{
${ }^{38}$ The $33.64 \%$ result from calculating $e^{0.29}=1.3364$.
} 
significant negative one in the Poisson regression (at the 5\% level). According to these specifications, trade is expected to decrease by $8.33 \%$ and $12.75 \%$ respectively, which is hard to make sense of economically. The coefficients for the in effect stage are highly significant and positive in the POLS, GLS and Tobit regressions but insignificant in the econometrically more adequate Poisson and negative-binomial regressions (with the coefficient being negative for Poisson and positive for negative-binomial).

The results for the multilateral trade agreement dummies are less robust than for the bilateral FTAs. The negative-binomial regressions show almost no significant coefficients with the exception of a slightly negative coefficient for the proposed stage of multilateral FTAs. Similarly, the results for the Poisson estimates are insignificant, except for positive effects of $8.33 \%$ in the framework agreement signed stage and $20.92 \%$ for implemented multilateral FTAs, which are significant at the level of 5\% and $1 \%$ respectively. The GLS and Tobit specifications reveal higher significance levels in general but also vary in the signs of their respective coefficients. Let us consider the following as an example: even though the proposed stage reveals a negative effect of $13.88 \%$ in the fixed and random effects GLS regressions, ${ }^{39}$ the consecutive stage has the opposite trait with a slightly higher significant coefficient. In the in effect stage, multilateral FTAs on average increase bilateral trade flows by $32.31 \%$ under the Tobit specification.

The results clearly show that the magnitude and sign of the estimates depend very much on the econometric specification. This is the case for the standard gravity variables as well as for the dummy variables reflecting FTA stages. Depending on our econometric specification, the results reflect anticipatory trade effects when a bilateral FTA is right before its negotiation stage. This effect seems to be robust in our various specifications and, most importantly, the negative-binomial regressions also reflect this trait. This specification arguably has the most appropriate properties as it allows for the inclusion of zero-trade flows, can be implemented in the existence of overdispersion and allows for the estimation with fixed effects. The Poisson specification, in comparison, does not address the overdispersion in our data. The differences in the coefficients and the significance levels between the negativebinomial and the Poisson method reveal a considerable discrepancy in the two models and point towards a misspecification due to overdispersion.

The Tobit estimates also control for zero-trade with the two drawbacks being, first, a slight data-manipulation (adding 1 to each trade observation for the log-transformation), and, second, missing fixed effects. Disregarding these issues, the respective results reflect even more significant trade effects under Tobit estimates for bilateral as well as multilateral trade

\footnotetext{
${ }^{39}$ The fixed effects approach was favoured over the random effects model by a Hausman-test.
} 
agreements. Not only does the anticipatory effect for bilateral FTAs remain highly significant but the coefficient for implemented agreements also signals increasing trade of almost $30 \%$. With Tobit, even the coefficients for multilateral FTAs are significantly positive at the $1 \%$ level for multilateral agreements in framework agreement singed and the in effect stages. With this specification, and controlled for year fixed effects, implemented multilateral FTAs seem to have a stronger effect on bilateral trade flows than bilateral FTAs.

\section{Conclusions}

The economies of East Asia have only since the turn of the millennium begun to pay attention to an institutionalisation of their trade relations. This has so far resulted in a vast amount of trade initiatives, on the bilateral and multilateral level. The availability of detailed data on FTAs with East Asian participation gives us the possibility to investigate the respective trade effects of different stages of implementation.

We augment the traditional gravity variables to estimate effects coming from different sorts of trade agreements and year-to-year changes in the stages of their implementation. We use different regression techniques, including pooled ordinary least squares, generalised least squares (GLS) with random effects, Tobit regression with random effects as well as the fixed effects estimations of GLS, Poisson and negative-binomial. The results depend very much on the econometric specification. We consider negative-binomial to be the most appropriate methodology because it accounts for overdispersion in the data and allows for estimation with fixed effects. The fact that we obtain partly contradictory empirical results when using different regression techniques highlights the need not only for caution when interpreting the findings, but also for prudence in the selection of the most appropriate econometric methodology.

Our results indicate that there are indeed anticipatory effects preceding the actual implementation of bilateral FTAs with East Asian participation. Particularly the stage in which bilateral trade agreements are (close to) being negotiated exposes significant positive trade effects. The results for the effect of multilateral trade agreements are less robust and, in most cases, insignificant. This suggests that the anticipation effects of bilateral agreements are larger, possibly because the realisation of bilateral agreements is considered more realistic than that of multilateral agreements, which due to the multiple parties involved are often more complicated to negotiate. This is also reflected by the afore-mentioned average time period that it takes for FTAs to reach a consecutive stage. Bilateral trade agreements correspond to a 
more rapid implementation process than multilateral initiatives. Another interpretation may be the actual depth of trade integration, such that bilateral FTAs provide a more comprehensive coverage of goods than multilateral agreements. The plausibility of this argument may be reconsidered in further research which takes a closer look at the heterogeneity of the included agreements.

An extension of our work would be to replicate our analysis for other country groupings, and examine whether our finding regarding the different trade creating effects of bilateral and multilateral trade agreements in pre-implementation stages remains applicable to a different regional context. This is only a matter of data availability. 


\section{Figures and Tables}

Figure 1: Evolution of FTAs with and within East Asia, by status; 1995-2008

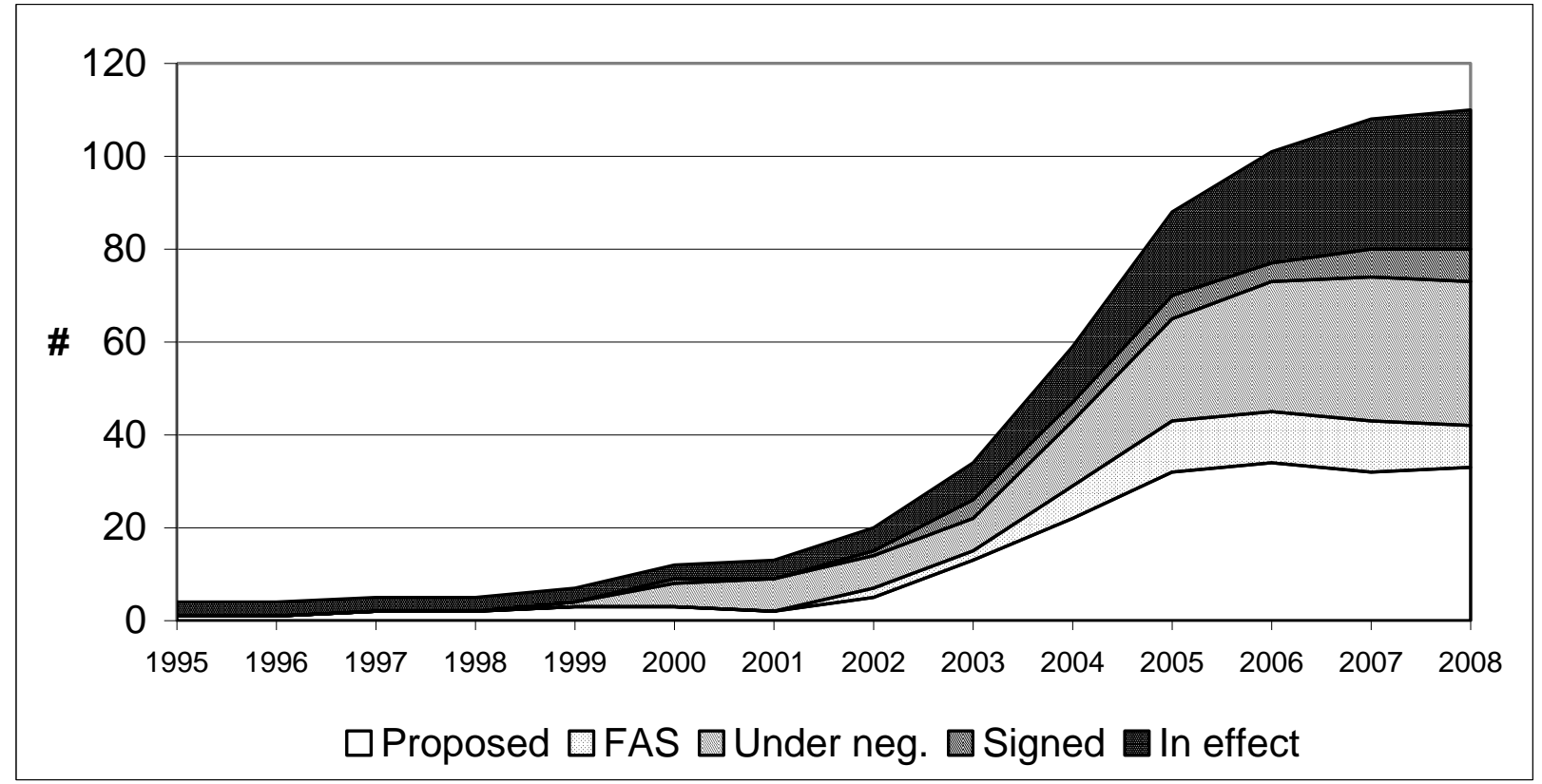

Source: Own illustration based on data from ADB (2009). Note: FAS= framework agreement signed, Under neg.= under negotiation; definitions of the respective statuses are given in Table 1.

Table 1: Definition of different statuses/stages of FTAs

\begin{tabular}{ll}
\hline \hline Stage & Definition \\
\hline Proposed & $\begin{array}{l}\text { Parties are considering a free trade agreement, establishing joint } \\
\text { study groups or joint task force, and conducting feasibility studies } \\
\text { to determine the desirability of entering into an FTA. }\end{array}$ \\
Framework agreement & $\begin{array}{l}\text { Parties initially negotiate the contents of a framework agreement, } \\
\text { which serves as a framework for future negotiations. }\end{array}$ \\
signed & $\begin{array}{l}\text { Parties begin negotiations without a framework agreement. } \\
\text { Under negotiation }\end{array}$ \\
Signed & $\begin{array}{l}\text { Phen the provisions of an FTA becomes effective, e.g. when tariff } \\
\text { In effect }\end{array}$ \\
\hline \hline
\end{tabular}

Source: ADB (2009) 
Table 2: Regressions by status of FTAs, Total trade

\begin{tabular}{|c|c|c|c|c|c|c|}
\hline & 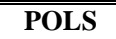 & $\overline{\text { GLS RE }}$ & $\overline{\text { GLS FE }}$ & Tobit RE & Poisson FE & NB FE \\
\hline Method & (1) & (2) & (3) & (4) & (5) & (6) \\
\hline Constant & 2.60 & 3.79 & 2.90 & $\begin{array}{l}--- \\
\end{array}$ & "--- & 2.33 \\
\hline \multirow[t]{2}{*}{$\operatorname{Ln}\left(\right.$ Distance $\left._{\mathrm{ij}}\right)$} & $-0.98 * * *$ & $-1.12 * * *$ & --- & $-0.65 * * *$ & --- & $-0.51 * * *$ \\
\hline & $(0.037)$ & $(0.100)$ & --- & $(0.106)$ & --- & $(0.094)$ \\
\hline \multirow[t]{2}{*}{ Border $_{\mathrm{ij}}$} & $0.82 * * *$ & $0.85^{* * *}$ & --- & $1.05^{* * *}$ & --- & -0.26 \\
\hline & $(0.100)$ & $(0.273)$ & --- & $(0.274)$ & --- & $(0.576)$ \\
\hline \multirow[t]{2}{*}{ Language $_{i j}$} & $0.98 * * *$ & $1.21 * * *$ & --- & $0.92 * * *$ & --- & $0.36^{* * * *}$ \\
\hline & $(0.065)$ & $(0.216)$ & --- & $(0.230)$ & --- & $(0.090)$ \\
\hline \multirow[t]{2}{*}{$\operatorname{Ln}\left(\mathrm{GDP}_{\mathrm{it}} \mathrm{GDP}_{\mathrm{jt}}\right)$} & $1.22 * * *$ & $1.09 * * *$ & $0.72 * * *$ & $0.84 * * *$ & $0.73 * * *$ & $0.47 * * *$ \\
\hline & $(0.009)$ & $(0.023)$ & $(0.039)$ & $(0.024)$ & $(0.063)$ & $(0.023)$ \\
\hline \multirow[t]{2}{*}{$\operatorname{Ln}\left(\operatorname{Pop}_{\mathrm{it}} \mathrm{Pop}_{\mathrm{jt}}\right)$} & $-0.11 * * *$ & 0.03 & $-0.89 * * *$ & 0.03 & -0.23 & $-0.13 * * *$ \\
\hline & $(0.010)$ & $(0.031)$ & $(0.168)$ & $(0.024)$ & $(0.248)$ & $(0.031)$ \\
\hline \multirow[t]{2}{*}{ WTO } & $0.29 * * *$ & $0.33 * * *$ & $0.36 * * *$ & $0.35^{* * * *}$ & $0.43^{* * *} *$ & $0.49 * * *$ \\
\hline & $(0.036)$ & $(0.036)$ & $(0.038)$ & $(0.051)$ & $(0.026)$ & $(0.067)$ \\
\hline \multirow[t]{2}{*}{ Bilateral - Proposed ${ }_{\mathrm{ijt}}$} & $0.32 * *$ & $0.07 *$ & 0.04 & $0.16^{* * * *}$ & 0.05 & $0.08 *$ \\
\hline & $(0.127)$ & $(0.038)$ & $(0.033)$ & $(0.050)$ & $(0.041)$ & $(0.046)$ \\
\hline \multirow[t]{2}{*}{ Bilateral $-\mathrm{FaS}_{\mathrm{ijt}}$} & $0.88 * * *$ & $0.19 * * *$ & $0.19 * * *$ & $0.29 * * *$ & $0.13 *$ & $0.33^{* * * *}$ \\
\hline & $(0.206)$ & $(0.060)$ & $(0.048)$ & $(0.050)$ & $(0.071)$ & $(0.054)$ \\
\hline \multirow[t]{2}{*}{ Bilateral - UnderNeg ${ }_{\mathrm{ijt}}$} & $0.90 * * *$ & 0.05 & -0.03 & 0.09 & -0.03 & 0.04 \\
\hline & $(0.152)$ & $(0.042)$ & $(0.029)$ & $(0.059)$ & $(0.065)$ & $(0.041)$ \\
\hline \multirow[t]{2}{*}{ Bilateral - Signed $\mathrm{ijt}_{\mathrm{j}}$} & $0.49 *$ & 0.03 & $-0.10 *$ & 0.07 & $-0.12^{* *}$ & $-0.08^{*}$ \\
\hline & $(0.285)$ & $(0.073)$ & $(0.051)$ & $(0.065)$ & $(0.047)$ & $(0.050)$ \\
\hline \multirow[t]{2}{*}{ Bilateral - InEffect.ijt } & $1.12 * * *$ & $0.21 * * *$ & $0.08^{*}$ & $0.26^{* * * *}$ & -0.13 & 0.06 \\
\hline & $(0.163)$ & $(0.062)$ & $(0.041)$ & $(0.088)$ & $(0.082)$ & $(0.096)$ \\
\hline \multirow[t]{2}{*}{ Multilat. - Proposed ${ }_{i j t}$} & -0.09 & $-0.13 * * *$ & $-0.13^{* * *}$ & -0.07 & 0.02 & $-0.04^{*}$ \\
\hline & $(0.062)$ & $(0.035)$ & $(0.035)$ & $(0.053)$ & $(0.032)$ & $(0.020)$ \\
\hline \multirow[t]{2}{*}{ Multilat. $-\mathrm{FaS}_{\mathrm{ijt}}$} & $0.84 * * *$ & $0.14 * * *$ & $0.14 * * *$ & $0.17 * * *$ & $0.08 * *$ & 0.01 \\
\hline & $(0.095)$ & $(0.043)$ & $(0.042)$ & $(0.060)$ & $(0.041)$ & $(0.036)$ \\
\hline \multirow[t]{2}{*}{ Multilat. - UnderNeg $\mathrm{ijt}_{\mathrm{j}}$} & $0.28 * * *$ & -0.09 & 0.08 & 0.02 & 0.03 & -0.03 \\
\hline & $(0.091)$ & $(0.056)$ & $(0.056)$ & $(0.054)$ & $(0.032)$ & $(0.038)$ \\
\hline \multirow[t]{2}{*}{ Multilat. - Singed ${ }_{\mathrm{ijt}}$} & $0.92 * * *$ & -0.07 & -0.04 & $0.06^{*}$ & 0.02 & -0.03 \\
\hline & $(0.116)$ & $(0.053)$ & $(0.052)$ & $(0.033)$ & $(0.058)$ & $(0.034)$ \\
\hline \multirow[t]{2}{*}{ Multilat. - InEffect. ${ }_{\text {ijt }}$} & $1.15^{* * * *}$ & $0.16^{* *}$ & 0.01 & $0.28 * * *$ & $0.19 * * *$ & -0.01 \\
\hline & $(0.083)$ & $(0.069)$ & $(0.062)$ & $(0.061)$ & $(0.068)$ & $(0.048)$ \\
\hline $\mathrm{R}^{2}$ & 0.76 & 0.75 & $0.25^{1}$ & --- & $\begin{array}{l}-- \\
\end{array}$ & --- \\
\hline Observations & 12,991 & 12,991 & 12,991 & 15,017 & 14,211 & 14,211 \\
\hline Year Effects & Yes & Yes & Yes & Yes & Yes & Yes \\
\hline
\end{tabular}

Note: $* * *, * *$ and $*$ denote significance at the 1\%,5\% and 10\% level; Robust standard errors in parentheses (Standard errors in Tobit and Poisson were bootstrapped); POLS=Pooled ordinary least squares, GLS=Generalised least squares, $\mathrm{RE}=$ random effects, $\mathrm{FE}=$ fixed effects; 1 : value denotes within $\mathrm{R}$-squared 


\section{Appendix}

Table 3: FTAs including East Asian countries

\begin{tabular}{|c|c|c|c|c|c|c|c|c|}
\hline Free Trade Agreements & Members & Prop. & FAS & $\begin{array}{l}\text { Under } \\
\text { neg. }\end{array}$ & Sign. & $\begin{array}{c}\text { In } \\
\text { Effect }\end{array}$ & $\begin{array}{c}\text { Intra- } \\
\text { EA }\end{array}$ & $\begin{array}{c}\text { Extra- } \\
\text { EA }\end{array}$ \\
\hline ASEAN Free Trade Area & $\begin{array}{l}\text { Brunei, Cambodia, Indonesia, Laos, Malaysia, } \\
\text { Myanmar, Philippines, Singapore, Thailand, } \\
\text { Vietnam }\end{array}$ & & & & & $\sqrt{ }$ & $\sqrt{ }$ & \\
\hline $\begin{array}{l}\text { ASEAN-Australia and New Zealand Free Trade } \\
\text { Agreement }\end{array}$ & ASEAN, Australia, New Zealand & & & $\sqrt{ }$ & & & & $\sqrt{ }$ \\
\hline $\begin{array}{l}\text { ASEAN-China Comprehensive Economic } \\
\text { Cooperation Agreement }\end{array}$ & ASEAN, China & & & & & $\sqrt{ }$ & $\sqrt{ }$ & \\
\hline ASEAN-EU Free Trade Agreement & $\begin{array}{l}\text { ASEAN, Austria, Belgium, Cyprus, Czech } \\
\text { Republic, Denmark, Estonia, Finland, France, } \\
\text { Germany, Greece, Hungary, Ireland, Italy, } \\
\text { Latvia, Lithuania, Luxembourg, Malta, Poland, } \\
\text { Portugal, Slovakia, Slovenia, Spain, Sweden, } \\
\text { Netherlands, United Kingdom }\end{array}$ & & & $\sqrt{ }$ & & & & $\sqrt{ }$ \\
\hline ASEAN-India Regional Trade and Investment Area & ASEAN, India & & $\sqrt{ }$ & & & & & $\sqrt{ }$ \\
\hline $\begin{array}{l}\text { ASEAN-Japan Comprehensive Economic } \\
\text { Partnership }\end{array}$ & ASEAN, Japan & & & & $\sqrt{ }$ & & $\sqrt{ }$ & \\
\hline $\begin{array}{l}\text { ASEAN-Korea Comprehensive Economic } \\
\text { Cooperation Agreement }\end{array}$ & ASEAN, Korea & & & & & $\sqrt{ }$ & $\sqrt{ }$ & \\
\hline Asia Pacific Trade Agreement & $\begin{array}{l}\text { Bangladesh, China, India, Korea, Laos, Sri } \\
\text { Lanka }\end{array}$ & & & & & $\sqrt{ }$ & & $\sqrt{ }$ \\
\hline Australia-Korea Free Trade Agreement & Australia, Korea & $\sqrt{ }$ & & & & & & $\sqrt{ }$ \\
\hline $\begin{array}{l}\text { Bay of Bengal Initiative for Multi-Sectoral Technical } \\
\text { and Economic Cooperation (BIMSTEC) Free Trade } \\
\text { Area }\end{array}$ & $\begin{array}{l}\text { Bangladesh, India, Nepal, Thailand, Bhutan, } \\
\text { Myanmar }\end{array}$ & & $\sqrt{ }$ & & & & & $\sqrt{ }$ \\
\hline Canada-Singapore Free Trade Agreement & Canada, Singapore & & & $\sqrt{ }$ & & & & $\sqrt{ }$ \\
\hline Chile - Vietnam Free Trade Agreement & Chile, Vietnam & & & $\sqrt{ }$ & & & & $\sqrt{ }$ \\
\hline $\begin{array}{l}\text { Comprehensive Economic Partnership Agreement } \\
\text { between Singapore and Sri Lanka }\end{array}$ & Singapore, Sri Lanka & $\sqrt{ }$ & & & & & & $\sqrt{ }$ \\
\hline Costa-Rica - China FTA & Costa Rica, China & $\sqrt{ }$ & & & & & & $\sqrt{ }$ \\
\hline East Asia Free Trade Area (ASEAN+3) & ASEAN, China, Japan, Korea & $\sqrt{ }$ & & & & & $\sqrt{ }$ & \\
\hline
\end{tabular}


Table 3: continued

Status (as of September 2008)

\begin{tabular}{|c|c|c|c|c|c|c|c|c|}
\hline Free Trade Agreements & Members & Prop. & FAS & $\begin{array}{l}\text { Under } \\
\text { neg. }\end{array}$ & Sign. & $\begin{array}{c}\text { In } \\
\text { Effect }\end{array}$ & $\begin{array}{c}\text { Intra- } \\
\text { EA }\end{array}$ & $\begin{array}{c}\text { Extra- } \\
\text { EA }\end{array}$ \\
\hline East Asia Summit Free Trade Area (ASEAN+6) & ASEAN+3, India, New Zealand, Australia & $\sqrt{ }$ & & & & & & $\sqrt{ }$ \\
\hline $\begin{array}{l}\text { European Free Trade Association-Singapore Free } \\
\text { Trade Agreement }\end{array}$ & $\begin{array}{l}\text { Singapore, Switzerland, Liechtenstein, } \\
\text { Norway, Iceland }\end{array}$ & & & & & $\sqrt{ }$ & & $\sqrt{ }$ \\
\hline $\begin{array}{l}\text { Gulf Cooperation Council-Singapore Free Trade } \\
\text { Agreement }\end{array}$ & $\begin{array}{l}\text { Singapore, Bahrain, Oman, Saudi Arabia, } \\
\text { Kuwait, Qatar, United Arab Emirates }\end{array}$ & & & $\sqrt{ }$ & & & & $\sqrt{ }$ \\
\hline $\begin{array}{l}\text { India-Indonesia Comprehensive Economic } \\
\text { Cooperation Arrangement }\end{array}$ & India, Indonesia & $\sqrt{ }$ & & & & & & $\sqrt{ }$ \\
\hline $\begin{array}{l}\text { India-Korea Comprehensive Economic Partnership } \\
\text { Agreement }\end{array}$ & India, Korea & & & $\sqrt{ }$ & & & & $\sqrt{ }$ \\
\hline $\begin{array}{l}\text { India-Singapore Comprehensive Economic } \\
\text { Cooperation Agreement }\end{array}$ & India, Singapore & & & & & $\sqrt{ }$ & & $\sqrt{ }$ \\
\hline India-Thailand Free Trade Area & India, Thailand & & $\sqrt{ }$ & & & & & $\sqrt{ }$ \\
\hline Indonesia-Australia Free Trade Agreement & Indonesia, Australia & $\sqrt{ }$ & & & & & & \\
\hline $\begin{array}{l}\text { Indonesia-European Free Trade Association Free } \\
\text { Trade Agreement }\end{array}$ & $\begin{array}{l}\text { Indonesia, Switzerland, Liechtenstein, Norway, } \\
\text { Iceland }\end{array}$ & $\sqrt{ }$ & & & & & & $\sqrt{ }$ \\
\hline Japan-Australia Economic Partnership Agreement & Japan, Australia & & & $\sqrt{ }$ & & & & $\sqrt{ }$ \\
\hline Japan-Brunei Free Trade Agreement & Japan, Brunei & & & & $\sqrt{ }$ & & $\sqrt{ }$ & \\
\hline Japan-Canada Free Trade Agreement & Japan, Canada & $\sqrt{ }$ & & & & & & $\sqrt{ }$ \\
\hline Japan-Chile Economic Partnership Agreement & Japan, Chile & & & & & $\sqrt{ }$ & & $\sqrt{ }$ \\
\hline $\begin{array}{l}\text { Japan-Gulf Cooperation Council Free Trade } \\
\text { Agreement }\end{array}$ & $\begin{array}{l}\text { Japan, Bahrain, Oman, Saudi Arabia, Kuwait, } \\
\text { Qatar, United Arab Emirates }\end{array}$ & & & $\sqrt{ }$ & & & & $\sqrt{ }$ \\
\hline Japan-India Economic Partnership Agreement & Japan, India & & & $\sqrt{ }$ & & & & $\sqrt{ }$ \\
\hline Japan-Indonesia Economic Partnership Agreement & Japan, Indonesia & & & & & $\sqrt{ }$ & $\sqrt{ }$ & \\
\hline Japan-Korea Free Trade Agreement & Japan, Korea & & & $\sqrt{ }$ & & & $\sqrt{ }$ & \\
\hline Japan-Malaysia Economic Partnership Agreement & Japan, Malaysia & & & & & $\sqrt{ }$ & $\sqrt{ }$ & \\
\hline Japan-Mexico Economic Partnership Agreement & Japan, Mexico & & & & & $\sqrt{ }$ & & $\sqrt{ }$ \\
\hline Japan-Philippines Economic Partnership Agreement & Japan, Philippines & & & & $\sqrt{ }$ & & $\sqrt{ }$ & \\
\hline $\begin{array}{l}\text { Japan-Singapore Economic Agreement for a New- } \\
\text { Age Partnership }\end{array}$ & Japan, Singapore & & & & & $\sqrt{ }$ & $\sqrt{ }$ & \\
\hline Japan-Switzerland Economic Partnership Agreement & Japan, Switzerland & & & $\sqrt{ }$ & & & & $\sqrt{ }$ \\
\hline Japan-Thailand Economic Partnership Agreement & Japan, Thailand & & & & & $\sqrt{ }$ & $\sqrt{ }$ & \\
\hline Japan-Vietnam Economic Partnership Agreement & Japan, Vietnam & & & $\sqrt{ }$ & & & $\sqrt{ }$ & \\
\hline
\end{tabular}


Status (as of September 2008)

\begin{tabular}{|c|c|c|c|c|c|c|c|c|}
\hline Free Trade Agreements & Members & Prop. & FAS & $\begin{array}{l}\text { Under } \\
\text { neg. }\end{array}$ & Sign. & $\begin{array}{c}\text { In } \\
\text { Effect }\end{array}$ & $\begin{array}{c}\text { Intra- } \\
\text { EA }\end{array}$ & $\begin{array}{c}\text { Extra- } \\
\text { EA }\end{array}$ \\
\hline Korea-Canada Free Trade Agreement & Korea, Canada & & & $\sqrt{ }$ & & & & $\sqrt{ }$ \\
\hline Korea-Chile Free Trade Agreement & Korea, Chile & & & & & $\sqrt{ }$ & & $\sqrt{ }$ \\
\hline $\begin{array}{l}\text { Korea-European Free Trade Association Free Trade } \\
\text { Agreement }\end{array}$ & $\begin{array}{l}\text { Korea, Switzerland, Liechtenstein, Norway, } \\
\text { Iceland }\end{array}$ & & & & & $\sqrt{ }$ & & $\sqrt{ }$ \\
\hline Korea-European Union Free Trade Agreement & $\begin{array}{l}\text { Korea, Austria, Belgium, Cyprus, Czech } \\
\text { Republic, Denmark, Estonia, Finland, France, } \\
\text { Germany, Greece, Hungary, Ireland, Italy, } \\
\text { Latvia, Lithuania, Luxembourg, Malta, Poland, } \\
\text { Portugal, Slovakia, Slovenia, Spain, Sweden, } \\
\text { Netherlands, United Kingdom }\end{array}$ & & & $\sqrt{ }$ & & & & $\sqrt{ }$ \\
\hline $\begin{array}{l}\text { Korea-Gulf Cooperation Council Free Trade } \\
\text { Agreement }\end{array}$ & $\begin{array}{l}\text { Korea, Bahrain, Oman, Saudi Arabia, Kuwait, } \\
\text { Qatar, United Arab Emirates }\end{array}$ & $\sqrt{ }$ & & & & & & $\sqrt{ }$ \\
\hline Korea-MERCOSUR Preferential Trading Agreement & Korea, Argentina, Brazil, Paraguay, Uruguay & $\sqrt{ }$ & & & & & & $\sqrt{ }$ \\
\hline $\begin{array}{l}\text { Korea-Mexico Strategic Economic Complementation } \\
\text { Agreement }\end{array}$ & Korea, Mexico & & & $\sqrt{ }$ & & & & $\sqrt{ }$ \\
\hline Korea-Singapore Free Trade Agreement & Korea, Singapore & & & & & $\sqrt{ }$ & $\sqrt{ }$ & \\
\hline Korea-South Africa Free Trade Agreement & Korea, Republic of South Africa & $\sqrt{ }$ & & & & & & $\sqrt{ }$ \\
\hline Korea-Thailand Free Trade Agreement & Korea, Thailand & $\sqrt{ }$ & & & & & $\sqrt{ }$ & \\
\hline Korea-United States Free Trade Agreement & Korea, United States & & & & $\sqrt{ }$ & & & $\sqrt{ }$ \\
\hline Laos-Thailand Preferential Trading Arrangement & Laos, Thailand & & & & & $\sqrt{ }$ & $\sqrt{ }$ & \\
\hline Malaysia-Australia Free Trade Agreement & Malaysia, Australia & & & $\sqrt{ }$ & & & & $\sqrt{ }$ \\
\hline Malaysia-Chile Free Trade Agreement & Malaysia, Chile & & & $\sqrt{ }$ & & & & $\sqrt{ }$ \\
\hline $\begin{array}{l}\text { Malaysia-India Comprehensive Economic } \\
\text { Cooperation Agreement }\end{array}$ & Malaysia, India & $\sqrt{ }$ & & & & & & $\sqrt{ }$ \\
\hline Malaysia-Korea Free Trade Agreement & Malaysia, Korea & $\sqrt{ }$ & & & & & $\sqrt{ }$ & \\
\hline Malaysia-New Zealand Free Trade Agreement & Malaysia, New Zealand & & & $\sqrt{ }$ & & & & $\sqrt{ }$ \\
\hline $\begin{array}{l}\text { Malaysia-Pakistan Closer Economic Partnership } \\
\text { Agreement }\end{array}$ & Malaysia, Pakistan & & & & & $\sqrt{ }$ & & $\sqrt{ }$ \\
\hline New Zealand-China Free Trade Agreement & New Zealand, China & & & & $\sqrt{ }$ & & & $\sqrt{ }$ \\
\hline $\begin{array}{l}\text { New Zealand-Hong Kong Closer Economic } \\
\text { Partnership }\end{array}$ & New Zealand, Hong Kong & & & $\sqrt{ }$ & & & & $\sqrt{ }$ \\
\hline New Zealand-Korea Closer Economic Partnership & New Zealand, Korea & $\sqrt{ }$ & & & & & & $\sqrt{ }$ \\
\hline $\begin{array}{l}\text { New Zealand-Singapore Closer Economic } \\
\text { Partnership }\end{array}$ & New Zealand, Singapore & & & & & $\sqrt{ }$ & & $\sqrt{ }$ \\
\hline
\end{tabular}


Status (as of September 2008)

\begin{tabular}{|c|c|c|c|c|c|c|c|c|}
\hline Free Trade Agreements & Members & Prop. & FAS & $\begin{array}{l}\text { Under } \\
\text { neg. }\end{array}$ & Sign. & $\begin{array}{c}\text { In } \\
\text { Effect }\end{array}$ & $\begin{array}{c}\text { Intra- } \\
\text { EA }\end{array}$ & $\begin{array}{c}\text { Extra- } \\
\text { EA }\end{array}$ \\
\hline Pakistan-Brunei Darussalam Free Trade Agreement & Pakistan, Brunei & $\sqrt{ }$ & & & & & & $\sqrt{ }$ \\
\hline Pakistan-Indonesia Free Trade Agreement & Pakistan, Indonesia & & $\sqrt{ }$ & & & & & $\sqrt{ }$ \\
\hline Pakistan-Philippines Free Trade Agreement & Pakistan, Philippines & $\sqrt{ }$ & & & & & & $\sqrt{ }$ \\
\hline Pakistan-Singapore Free Trade Agreement & Pakistan, Singapore & & & $\sqrt{ }$ & & & & $\sqrt{ }$ \\
\hline Pakistan-Thailand Free Trade Agreement & Pakistan, Thailand & $\sqrt{ }$ & & & & & & $\sqrt{ }$ \\
\hline $\begin{array}{l}\text { People's Republic of China-Australia Free Trade } \\
\text { Agreement }\end{array}$ & China, Australia & & $\sqrt{ }$ & & & & & $\sqrt{ }$ \\
\hline $\begin{array}{l}\text { People's Republic of China-Chile Free Trade } \\
\text { Agreement }\end{array}$ & China, Chile & & & & & $\sqrt{ }$ & & $\sqrt{ }$ \\
\hline $\begin{array}{l}\text { People's Republic of China-Gulf Cooperation } \\
\text { Council Free Trade Agreement }\end{array}$ & $\begin{array}{l}\text { China, Bahrain, Oman, Saudi Arabia, Kuwait, } \\
\text { Qatar, United Arab Emirates }\end{array}$ & & & $\sqrt{ }$ & & & & $\sqrt{ }$ \\
\hline $\begin{array}{l}\text { People's Republic of China-Hong Kong Closer } \\
\text { Economic Partnership Arrangement }\end{array}$ & China, Hong Kong & & & & & $\sqrt{ }$ & $\sqrt{ }$ & \\
\hline $\begin{array}{l}\text { People's Republic of China-Iceland Free Trade } \\
\text { Agreement }\end{array}$ & China, Iceland & & $\sqrt{ }$ & & & & & $\sqrt{ }$ \\
\hline $\begin{array}{l}\text { People's Republic of China-India Regional Trading } \\
\text { Arrangement }\end{array}$ & China, India & $\sqrt{ }$ & & & & & & $\sqrt{ }$ \\
\hline $\begin{array}{l}\text { People's Republic of China-Japan-Korea Free Trade } \\
\text { Agreement }\end{array}$ & China, Japan & $\sqrt{ }$ & & & & & $\sqrt{ }$ & \\
\hline $\begin{array}{l}\text { People's Republic of China-Korea Free Trade } \\
\text { Agreement }\end{array}$ & China, Korea & $\sqrt{ }$ & & & & & $\sqrt{ }$ & \\
\hline $\begin{array}{l}\text { People's Republic of China-Macao Closer Economic } \\
\text { Partnership Arrangement }\end{array}$ & China, Macao & & & & & $\sqrt{ }$ & & $\sqrt{ }$ \\
\hline $\begin{array}{l}\text { People's Republic of China-Norway Free Trade } \\
\text { Agreement }\end{array}$ & China, Norway & $\sqrt{ }$ & & & & & & $\sqrt{ }$ \\
\hline $\begin{array}{l}\text { People's Republic of China-Pakistan Free Trade } \\
\text { Agreement }\end{array}$ & China, Pakistan & & & & & $\sqrt{ }$ & & $\sqrt{ }$ \\
\hline $\begin{array}{l}\text { People's Republic of China-Peru Free Trade } \\
\text { Agreement }\end{array}$ & China, Peru & $\sqrt{ }$ & & & & & & $\sqrt{ }$ \\
\hline $\begin{array}{l}\text { People's Republic of China-Singapore Free Trade } \\
\text { Agreement }\end{array}$ & China, Singapore & & & $\sqrt{ }$ & & & $\sqrt{ }$ & \\
\hline $\begin{array}{l}\text { People's Republic of China-South Africa Free Trade } \\
\text { Agreement }\end{array}$ & China, Republic of South Africa & $\sqrt{ }$ & & & & & & $\sqrt{ }$ \\
\hline
\end{tabular}


Table 3: continued

\begin{tabular}{|c|c|c|c|c|c|c|c|c|}
\hline Free Trade Agreements & Members & Prop. & FAS & $\begin{array}{l}\text { Under } \\
\text { neg. }\end{array}$ & Sign. & $\begin{array}{c}\text { In } \\
\text { Effect }\end{array}$ & $\begin{array}{c}\text { Intra- } \\
\text { EA }\end{array}$ & $\begin{array}{c}\text { Extra- } \\
\text { EA }\end{array}$ \\
\hline $\begin{array}{l}\text { People's Republic of China-South African Customs } \\
\text { Union Free Trade Agreement }\end{array}$ & $\begin{array}{l}\text { China, Republic of South Africa, Botswana, } \\
\text { Namibia, Swaziland, Lesotho }\end{array}$ & & & $\sqrt{ }$ & & & & $\sqrt{ }$ \\
\hline $\begin{array}{l}\text { People's Republic of China-Thailand Free Trade } \\
\text { Agreement }\end{array}$ & China, Thailand & & & & & $\sqrt{ }$ & $\sqrt{ }$ & \\
\hline $\begin{array}{l}\text { Preferential Tariff Arrangement-Group of Eight } \\
\text { Developing Countries }\end{array}$ & $\begin{array}{l}\text { Bangladesh, Indonesia, Malaysia, Pakistan, } \\
\text { Egypt, Iran, Nigeria, Turkey }\end{array}$ & & & & $\sqrt{ }$ & & & $\sqrt{ }$ \\
\hline $\begin{array}{l}\text { Shanghai Cooperation Organization Free Trade } \\
\text { Agreement }\end{array}$ & $\begin{array}{l}\text { China, Kyrgyz Republic, Tajikistan, } \\
\text { Kazakhstan, Russia, Uzbekistan }\end{array}$ & $\sqrt{ }$ & & & & & & $\sqrt{ }$ \\
\hline Singapore-Australia Free Trade Agreement & Singapore, Australia & & & & & $\sqrt{ }$ & & $\sqrt{ }$ \\
\hline Singapore-Bahrain Free Trade Agreement & Singapore, Bahrain & $\sqrt{ }$ & & & & & & $\sqrt{ }$ \\
\hline $\begin{array}{l}\text { Singapore-Egypt Comprehensive Economic } \\
\text { Cooperation Agreement }\end{array}$ & Singapore, Egypt & & & $\sqrt{ }$ & & & & $\sqrt{ }$ \\
\hline Singapore-Jordan Free Trade Agreement & Singapore, Jordan & & & & & $\sqrt{ }$ & & $\sqrt{ }$ \\
\hline Singapore-Kuwait Free Trade Agreement & Singapore, Kuwait & & & $\sqrt{ }$ & & & & $\sqrt{ }$ \\
\hline Singapore-Mexico Free Trade Agreement & Singapore, Mexico & & & $\sqrt{ }$ & & & & $\sqrt{ }$ \\
\hline Singapore-Panama Free Trade Agreement & Singapore, Panama & & & & & $\sqrt{ }$ & & $\sqrt{ }$ \\
\hline Singapore-Peru Free Trade Agreement & Singapore, Peru & & & & $\sqrt{ }$ & & & $\sqrt{ }$ \\
\hline Singapore-Qatar Free Trade Agreement & Singapore, Qatar & & & $\sqrt{ }$ & & & & $\sqrt{ }$ \\
\hline Singapore-Ukraine Free Trade Agreement & Singapore, Ukraine & & & $\sqrt{ }$ & & & & $\sqrt{ }$ \\
\hline $\begin{array}{l}\text { Singapore-United Arab Emirates Free Trade } \\
\text { Agreement }\end{array}$ & Singapore, United Arab Emirates & $\sqrt{ }$ & & & & & & $\sqrt{ }$ \\
\hline Thailand-Australia Free Trade Agreement & Thailand, Australia & & & & & $\sqrt{ }$ & & $\sqrt{ }$ \\
\hline Thailand-Bahrain Free Trade Agreement & Thailand, Bahrain & & $\sqrt{ }$ & & & & & $\sqrt{ }$ \\
\hline Thailand-Chile Free Trade Agreement & Thailand, Chile & $\sqrt{ }$ & & & & & & $\sqrt{ }$ \\
\hline $\begin{array}{l}\text { Thailand-European Free Trade Association Free } \\
\text { Trade Agreement }\end{array}$ & $\begin{array}{l}\text { Thailand, Switzerland, Liechtenstein, Norway, } \\
\text { Iceland }\end{array}$ & & & $\sqrt{ }$ & & & & $\sqrt{ }$ \\
\hline Thailand-MERCOSUR Free Trade Agreement & $\begin{array}{l}\text { Thailand, Argentina, Brazil, Paraguay, } \\
\text { Uruguay }\end{array}$ & $\sqrt{ }$ & & & & & & $\sqrt{ }$ \\
\hline $\begin{array}{l}\text { Thailand-New Zealand Closer Economic Partnership } \\
\text { Agreement }\end{array}$ & Thailand, New Zealand & & & & & $\sqrt{ }$ & & $\sqrt{ }$ \\
\hline Thailand-Peru Free Trade Agreement & Thailand, Peru & & $\sqrt{ }$ & & & & & $\sqrt{ }$ \\
\hline
\end{tabular}


Table 3: continued

Status (as of September 2008)

\begin{tabular}{|c|c|c|c|c|c|c|c|c|}
\hline Free Trade Agreements & Members & Prop. & FAS & $\begin{array}{l}\text { Under } \\
\text { neg. }\end{array}$ & Sign. & $\begin{array}{c}\text { In } \\
\text { Effect }\end{array}$ & $\begin{array}{c}\text { Intra- } \\
\text { EA }\end{array}$ & $\begin{array}{c}\text { Extra- } \\
\text { EA }\end{array}$ \\
\hline $\begin{array}{l}\text { Trade Preferential System of the Organization of the } \\
\text { Islamic Conference }\end{array}$ & $\begin{array}{l}\text { Bahrain, Cameroon, Guinea, Jordan, Libyan } \\
\text { Arab Jamahiriya, Pakistan, Syrian Arab } \\
\text { Republic, Turkey, United Arab Emirates, } \\
\text { Bangladesh, Egypt, Iran, Lebanon, Malaysia, } \\
\text { Senegal, Tunisia, Uganda }\end{array}$ & & $\sqrt{ }$ & & & & & $\sqrt{ }$ \\
\hline $\begin{array}{l}\text { Trans-Pacific Strategic Economic Partnership } \\
\text { Agreement }\end{array}$ & Brunei, New Zealand, Chile, Singapore & & & & & $\sqrt{ }$ & & $\sqrt{ }$ \\
\hline United States-Brunei Free Trade Agreement & United States, Brunei & $\sqrt{ }$ & & & & & & $\sqrt{ }$ \\
\hline United States-Indonesia Free Trade Agreement & United States. Indonesia & $\sqrt{ }$ & & & & & & $\sqrt{ }$ \\
\hline United States-Malaysia Free Trade Agreement & United States, Malaysia & & & $\sqrt{ }$ & & & & $\sqrt{ }$ \\
\hline United States-Philippines Free Trade Agreement & United States, Philippines & $\sqrt{ }$ & & & & & & $\sqrt{ }$ \\
\hline United States-Singapore Free Trade Agreement & United States, Singapore & & & & & $\sqrt{ }$ & & $\sqrt{ }$ \\
\hline United States-Thailand Free Trade Agreement & United States, Thailand & & & $\sqrt{ }$ & & & & $\sqrt{ }$ \\
\hline
\end{tabular}

Source: Own compilation based on data from ADB (2009)

Note: Prop.=Proposed; FAS=Framework agreement signed; Under. neg.=Under negotiation; Sign.=Signed; Intra-EA describes FTA initiatives that consist solely of East Asian economies. Extra-EA includes at least one country from outside of East Asia. 
Table 4: Countries included in the data set

\begin{tabular}{|c|c|c|}
\hline Argentina & Ireland & Peru \\
\hline Australia & Italy & Philippines \\
\hline Austria & Japan & Poland \\
\hline Bahrain & Jordan & Portugal \\
\hline Bangladesh & Kazakhstan & Qatar \\
\hline Belgium & Korea & Russia \\
\hline Bhutan & Kuwait & Saudi Arabia \\
\hline Botswana & Kyrgyz Republic & Senegal \\
\hline Brazil & Laos & Singapore \\
\hline Brunei & Latvia & Slovakia \\
\hline Cambodia & Lebanon & Slovenia \\
\hline Cameroon & Lesotho & South Africa \\
\hline Canada & Libya & Spain \\
\hline Chile & Liechtenstein & Sri Lanka \\
\hline China & Lithuania & Swaziland \\
\hline Cyprus & Luxembourg & Sweden \\
\hline Czech Republic & Macao & Switzerland \\
\hline Denmark & Malaysia & Syrian Arab Republic \\
\hline Egypt & Malta & Tajikistan \\
\hline Estonia & Mexico & Thailand \\
\hline Finland & Myanmar & Tunisia \\
\hline France & Namibia & Turkey \\
\hline Germany & Nepal & Uganda \\
\hline Greece & Netherlands & Ukraine \\
\hline Guinea & New Zealand & United Arab Emirates \\
\hline Hong Kong & Nigeria & United Kingdom \\
\hline Hungary & Norway & United States \\
\hline Iceland & Oman & Uruguay \\
\hline India & Pakistan & Uzbekistan \\
\hline Indonesia & Panama & Vietnam \\
\hline Iran & Paraguay & \\
\hline
\end{tabular}




\section{References}

ADB (Asian Development Bank) (2006). Asian Development Outlook 2006: Routes for Asia’s Trade. Asian Development Bank, Manila.

ADB (Asian Development Bank) (2009). Asia Regional Integration Center. Asian Development Bank, Manila. http://aric.adb.org.

Allison, P. D., Waterman, R. P. (2002). Fixed-Effects Negative Binomial Regression Models. Sociological Methodology, 32 (1), 247-265.

Anderson, J. E. (1979). A Theoretical Foundation for the Gravity Equation. American Economic Review, 69 (1), 106-116.

Anderson, J. E., van Wincoop, E. (2003). Gravity with Gravitas: A Solution to the Border Puzzle. American Economic Review, 93 (1), 170-192.

Baier, S. L., Bergstrand, J. H. (2002). On the Endogeneity of International Trade Flows and Free Trade Agreements. Mimeo, Federal Reserve Bank of Atlanta.

Baier, S. L., Bergstrand, J. H. (2004). Economic Determinants of Free Trade Agreements. Journal of International Economics, 64 (1), 72-95.

Baier, S. L., Bergstrand, J. H. (2007). Do Free Trade Agreements Actually Increase Members' International Trade? Journal of International Economics, 71 (1), 72-95.

Balding, C. (2010). Joining the World Trade Organization: What is the Impact? Review of International Economics, 18 (1), 193-206.

Baldwin, R. (1993). A Domino Theory of Regionalism. NBER Working Paper 4465, National Bureau of Economic Research, Cambridge, MA.

Baldwin, R. (2006). Managing the Noodle Bowl: The Fragility of East Asian Regionalism. CEPR Discussion Paper 5561, Centre for Economic Policy Research, London.

Baldwin, R., Taglioni, D. (2006). Gravity for Dummies and Dummies for Gravity Equations. CEPR Discussion Paper 5850, Centre for Economic Policy Research, London.

Bergstrand, J. H. (1985). The Gravity Equation in International Trade: Some Microeconomic Foundations and Empirical Evidence. Review of Economics and Statistics, 67 (3), $474-$ 481.

Bhagwati, H. (1995). US Trade Policy: The Infatuation with Free Trade Areas. In J. Bhagwati and A. Krueger (Eds.), The Dangerous Drift to Preferential Trade Agreements, Washington D. C.: AEI Press.

Blomström, M., Kokko, A. (1997). Regional Integration and Foreign Direct Investment. Policy Research Working Paper 1750, World Bank, Washington D.C. 
Caporale, M. C., Rault C., Sova, R., Sova, A. (2009). On the Bilateral Trade Effects of Free Trade Agreements between the EU-15 and the CEEC-4 Countries. Review of World Economics/Weltwirtschaftliches Archiv, 145 (2), 189-206.

CEPII (Centré d'Études Prospectives et d'Informations Internationales) (2009). Database on Bilateral Distance. Centre d'Etudes Prospectives et d'Informations Internationales, Paris. http://www.cepii.fr/anglaisgraph/bdd/distances.htm.

Coulibaly, S. (2006). Evaluating the Trade and Welfare Effects of Developing RTAs. Cahiers de Recherches Economiques du Département d'Econométrie et d'Economie politique (DEEP) 06.03., Université de Lausanne.

Croce, E., Juan Ramón, V. H., Zhu, F. (2004). Performance of Western Hemisphere Trading Blocs: A Cost-Corrected Gravity Approach. IMF Working Paper 04/109, International Monetary Fund, Washington D.C.

Deardorff, A. V. (1995). Determinants of Bilateral Trade: Does Gravity Work in a Neoclassical World? NBER Working Paper 5377, National Bureau of Economic Research, Cambridge, MA.

Dent, C. M. (2006). New Free Trade Agreements in the Asia-Pacific. Basingstoke: Palgrave MacMillan.

Dobson, W. (2001). Deeper Integration in East Asia: Regional Institutions and the International Economic System. World Economy, 24 (8), 995-1018.

Eichengreen, B., Irwin, D. A. (1996). The Role of History in Bilateral Trade Flows. NBER Working Paper 5565, National Bureau of Economic Research, Cambridge, MA.

Elliott, R. J. R., Ikemoto, K. (2004). AFTA and the Asian Crisis: Help or Hindrance to ASEAN Intra-Regional Trade? Asian Economic Journal, 18 (1), 1-23.

Feenstra, R. (2004). Advanced International Trade: Theory and Evidence. Princeton: Princeton University Press.

Frankel, J. A. (1997). Regional Trading Blocs in the World Economic System. Washington D.C.: Institute for International Economics.

Fratianni, M., Marchionne, F. (2009). Trade Costs and Economic Development. Mimeo, Indiana University.

Freund, C. L., McLaren, J. E. (1999). On the Dynamics of Trade Diversion: Evidence from Four Trade Blocs. International Finance Discussion Papers 637, Board of Governors of the Federal Reserve System.

Ghosh, S., Yamarik, S. (2004). Are Regional Trading Agreements Trade Creating? An Application of Extreme Bounds Analysis. Journal of International Economics, 63 (2), 369-395. 
Hau, C. T. T., Dickie, P. M. (2006). Economic Transition in Vietnam: Doi Moi to WTO. PPTP Studies Series 1/2006, Asian Development Bank (Public Policy Training Program), Hanoi.

Haveman, J., Hummels, D. (1998). Trade Creation and Trade Diversion. New Empirical Results. Journal of Transnational Management Development, 3 (2), 47-72.

Helpman, E. (1987). Imperfect Competition and International Trade: Evidence from Fourteen Industrial Countries. Journal of the Japanese and International Economies, 1 (1), 62-81. Helpman, E., Melitz, M., Rubinstein, A. (2008). Estimating Trade Flows: Trading Partners and Trading Volumes. Quarterly Journal of Economics, 123 (2), 441-487.

IMF (International Monetary Fund) (2008). Direction of Trade Statistics. CD-ROM, International Monetary Fund, Washington D.C.

IMF (International Monetary Fund) (2009). World Economic Outlook Database, Online (April, 2009).

International Monetary Fund, Washington D.C. http://www.imf.org/external/pubs/ft/weo/2009/01/weodata/index.aspx. Accessed April 2009).

Kaufmann, D., Kraay, A., Mastruzzi, M. (2008). Governance Matters 7: Aggregate and Individual Governance Indicators 1996-2007. Policy Research Working Paper 4654, Wold Bank, Washington D.C.

Kawai, M. (2004). Trade and Investment Integration for Development in East Asia: A Case for the Trade-FDI Nexus. Mimeo, University of Tokyo.

Kawai, M. (2007). Evolving Economic Architecture in East Asia. ADB Institute Discussion Paper 84, Asian Development Bank Institute, Tokyo.

Kose, M. A., Meredith, G. M., Towe, C. M. (2004). How has NAFTA Affected the Mexican Economy? Review and Evidence. IMF Working Paper 04/59, International Monetary Fund, Washington D.C.

Krueger, A. O. (1999). Trade Creation and Trade Diversion Under NAFTA. NBER Working Paper 7429, National Bureau of Economic Research, Cambridge, MA.

Langhammer, R. J. (2007). The Asian Way of Regional Integration: Are There Lessons from Europe? Kiel Economic Policy Papers 7, Kiel Institute for the World Economy.

Linnemann, H. (1966). An Econometric Study of International Trade Flows. Amsterdam: North-Holland.

Magee, C. S. (2003). Endogenous Preferential Trade Agreements: An Empirical Analysis. B.E. Journal of Economic Analysis and Policy, 2 (1), Article 15.

Magee, C. S. (2008). New Measures of Trade Creation and Trade Diversion. Journal of International Economics, 75 (2), 349-362. 
Mansfield, E. D., Milner, H. V., Rosendorff, B. P. (2002). Why Democracies cooperate more: Electoral Control and International Trade Agreements. International Organization, 56 (3), 477-513.

Medvedev, D. (2010). Preferential Trade Agreements and their Role in World Trade. Review of World Economics/Weltwirtschaftliches Archiv, 146 (2), 199-222.

Melitz, J. (2008). Language and Foreign Trade. European Economic Review, 52 (4), 667-699.

Pöyhönen, P. (1963). A Tentative Model for the Volume of Trade between Countries. Weltwirtschaftliches Archiv/Review of World Economics, 90 (1), 93-100.

Rose, A. K. (2004). Do We Really Know that the WTO Increases Trade? American Economic Review, 94 (1), 98-114.

Rosendorff, B. P. (2005). Do Democracies Trade More Freely. Mimeo, New York University. Santos Silva, J. M. C., Tenreyro, S. (2006). The Log of Gravity. Review of Economics and Statistics, 88 (4), 641-658.

Soloaga, I., Wilson, J. S., Mejía, A. (2006). Moving Forward Faster: Trade Facilitation Reform and Mexican Competitiveness. Policy Research Working Paper 3953, World Bank, Washington D.C.

Subramanian, A., Wei, S.-J. (2007). The WTO promotes Trade, strongly but unevenly. Journal of International Economics, 72 (1), 151-175.

Tinbergen, J. (1962). Shaping the World Economy: Suggestions for an International Economic Policy. New York: Twentieth Century Fund.

Vicard, V. (2009). On Trade Creation and Regional Trade Agreements: Does Depth matter? Review of World Economics/Weltwirtschaftliches Archiv, 145 (2), 167-187.

Winkelmann, R. (2008). Econometric Analysis of Count Data. Berlin: Springer.

Wonnacott, P., Lutz, M. (1989). Is there a Case for Free Trade Areas? In J.J. Schott (Ed.), Free Trade Areas and U.S. Trade Policy. Washington D.C.: Institute for International Economics.

Wooldridge, J. (2002). Econometric Analysis of Cross Section and Panel Data. Cambridge, MA.: MIT Press. 